Supporting Information

\title{
Facile Preparation of Highly Conductive Metal Oxides by Self-combustion for Solution-processed Thermoelectric Generators
}

\author{
Young Hun Kang, Kwang-Suk Jang, Changjin Lee, and Song Yun Cho* \\ Division of Advanced Materials, Korea Research Institute of Chemical Technology, 141 Gajeong-ro, \\ Yuseong-gu, Daejeon 34114, Republic of Korea, E-mail: scho@krict.re.kr
}


(a)

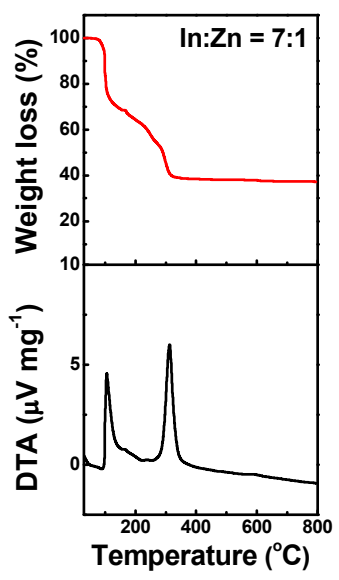

(b)

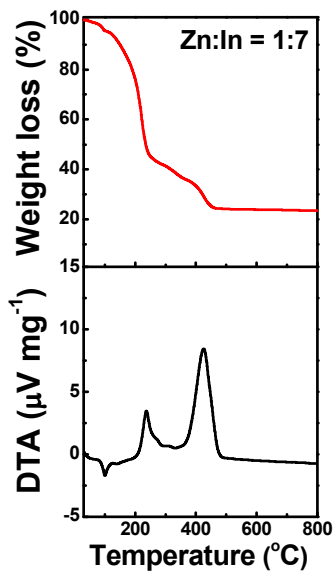

Figure S1. Thermal behaviors of the IZO precursors prepared from In:Zn= (a) 7:1 and (b) 1:7.

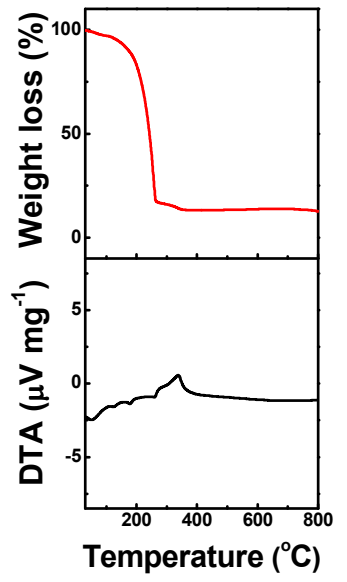

Figure S2. Thermal behaviors of the non-combustive IZO precursors prepared from indium acetylacetonate and zinc acetylacetonate with $\operatorname{In}: \mathrm{Zn}=6: 2$. 


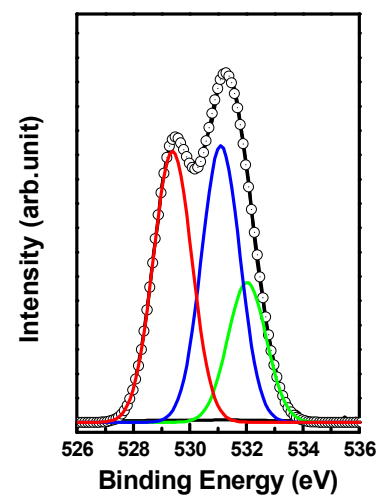

Figure S3. XPS spectra of the IZO thin films with a composition of $\operatorname{In}: \mathrm{Zn}=6: 2$ at the annealing temperature of $300^{\circ} \mathrm{C}$.

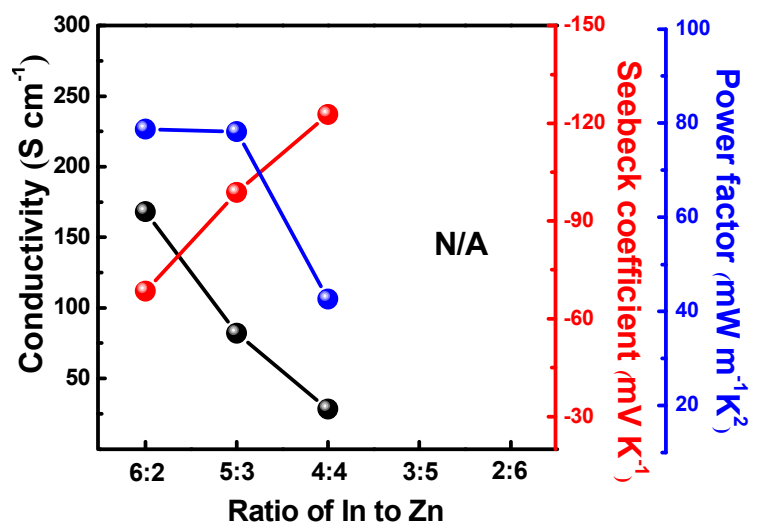

Figure S4. Thermoelectric properties of the IZO thin films according to composition ratios of In to $\mathrm{Zn}$ at the annealing temperature of $300{ }^{\circ} \mathrm{C}$ : electrical conductivity (black circles), Seebeck coefficient (red circles), and power factor (blue circles). 


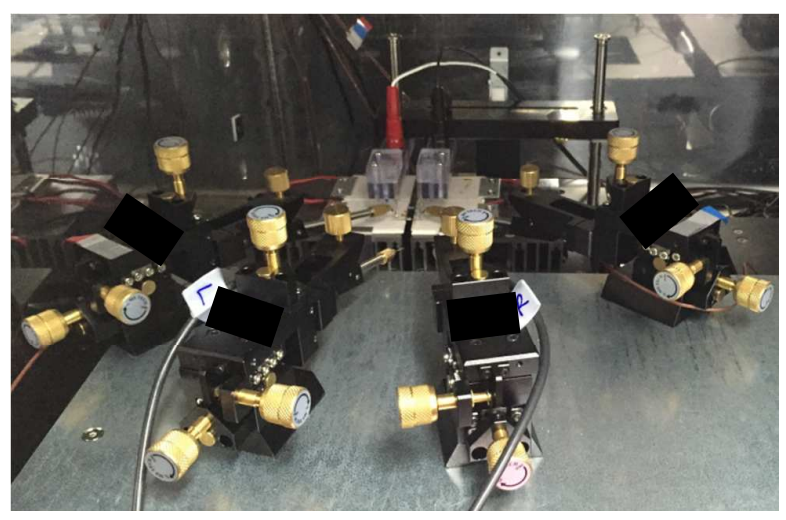

Figure S5. Photo of the Seebeck coefficient measurement set-up.

Table S1. Electrical and Thermoelectric Characteristics of the IZO Thin Films Annealed at $300{ }^{\circ} \mathrm{C}$.

\begin{tabular}{cccc}
\hline $\begin{array}{c}\text { molar composition ratio of } \\
\text { In to } \mathrm{Zn}\end{array}$ & $\begin{array}{c}\text { conductivity } \\
\left(\mathrm{S} \mathrm{cm}^{-1}\right)\end{array}$ & $\begin{array}{c}\text { Seebeck coefficient } \\
\left(\mu \mathrm{V} \mathrm{K}^{-1}\right)\end{array}$ & $\begin{array}{c}\text { power factor } \\
\left(\mu \mathrm{W} \mathrm{m}^{-1} \mathrm{~K}^{-2}\right)\end{array}$ \\
\hline $6: 2$ & 168 & 68.5 & 78.7 \\
$5: 3$ & 82 & 98.8 & 78.2 \\
$4: 4$ & 28.3 & 122.7 & 42.6 \\
$3: 5$ & $\mathrm{~N} / \mathrm{A}$ & $\mathrm{N} / \mathrm{A}$ & $\mathrm{N} / \mathrm{A}$ \\
$2: 6$ & $\mathrm{~N} / \mathrm{A}$ & $\mathrm{N} / \mathrm{A}$ & $\mathrm{N} / \mathrm{A}$ \\
\hline
\end{tabular}


Table S2. Electrical and Thermoelectric Characteristics of the IZO Thin Films Prepared from Non-combustive IZO Precursors with In: $\mathrm{Zn}=6: 2$ at $350{ }^{\circ} \mathrm{C}$.

\begin{tabular}{cccc}
\hline $\begin{array}{c}\text { IZO } \\
\text { precursor }\end{array}$ & $\begin{array}{c}\text { conductivity } \\
\left(\mathrm{S} \mathrm{cm}^{-1}\right)\end{array}$ & $\begin{array}{c}\text { Seebeck coefficient } \\
\left(\mu \mathrm{V} \mathrm{K}^{-1}\right)\end{array}$ & $\begin{array}{c}\text { power factor } \\
\left(\mu \mathrm{W} \mathrm{m}^{-1} \mathrm{~K}^{-2}\right)\end{array}$ \\
\hline $\begin{array}{c}\text { indium nitrate/ } \\
\text { zinc nitrate }\end{array}$ & 96.4 & 67.1 & 43.4 \\
$\begin{array}{c}\text { indium acetylacetonate/ } \\
\text { zinc acetylacetonate }\end{array}$ & $\mathrm{N} / \mathrm{A}$ & $\mathrm{N} / \mathrm{A}$ & $\mathrm{N} / \mathrm{A}$ \\
\hline
\end{tabular}

